$\underline{\beta}=-m$

\title{
Comparative pharmacokinetics and absolute bioavailabilities of two enrofloxacin generic preparations after single intracrop bolus administrations to broiler chickens
}

\author{
Nasser Ehmeza ${ }^{1}$, Abdelrazzag Elmajdoub ${ }^{1}$, Abubakr El-Mahmoudy ${ }^{2} *$ \\ ${ }^{1}$ Department of Pharmacology, Toxicology and Forensic Medicine, Faculty of Veterinary Medicine, \\ University of Tripoli, 13662 Tripoli, Libya \\ ${ }^{2}$ Department of Pharmacology, Faculty of Veterinary Medicine, Benha University, 13736 Moshtohor, Egypt \\ *Corresponding author E-mail: a.elmahmoudy@fvtm.bu.edu.eg
}

\begin{abstract}
The pharmacokinetics and absolute bioavailabilities of two generics of enrofloxacin (ENRO) $10 \%$ oral solution formulation at a dose of $10 \mathrm{mg} / \mathrm{Kg}$ body weight were compared after single intracrop (i.c.) bolus administrations in reference to single intravenous (i.v.) standard ENRO administration in broilers using a randomized parallel design. The two tested formulations were Enrol ${ }^{\circledR}\left(\mathrm{Medmac}^{\circledR}\right.$, Amman, Jor- $^{-}$ dan) as ENRO-A and Syvaquinol ${ }^{\circledR}$ (Syva ${ }^{\circledR}$, Leon, Spain) as ENRO-B 10\% oral solutions. An HPLC assay using pure ENRO base as a standard was used to measure concentrations of ENRO from the selected sources in plasma collected at predetermined time points up to 24 hours. The pharmacokinetic analysis of the C-T data was performed using non-compartmental analysis based on statistical moment theory with the help of computerized WinNonlin program (Version 5.3, Pharsight ${ }^{\circledR}$ Corporation, St. Louis, USA). The maximum plasma concentrations $\left(\mathrm{C}_{\max }\right)$ for ENRO-A and ENRO-B were $1.61 \pm 0.203$ and $1.79 \pm 0.283 \mu \mathrm{g} / \mathrm{mL}$, respectively, attained at time to peak $\left(\mathrm{T}_{\max }\right)$ of $2 \mathrm{~h}$. Elimination half-lives $\left(\mathrm{t}_{1 / 2 \beta}\right)$ were $8.391 \pm 0.312$ and $8.458 \pm 0.906 \mathrm{~h}$, respectively. While areas under plasma concentration-time curves $\left(\mathrm{AUC}_{0-\infty}\right)$, and systemic bioavailabilities $(\mathrm{F})$ were $12.744 \pm 2.951$ and $14.354 \pm 2.85 \mathrm{mg} . \mathrm{h} / \mathrm{L}$; and $78.96 \pm 6.728$ and $88.94 \pm$ $10.89 \%$ for ENRO-A and ENRO-B, respectively. It could be concluded that despite the superior pharmacokinetic profile of ENRO-B over ENRO-A, however, both generics were within the FDA and EMA bioequivalence acceptance range of $80 \%-125 \%$ and thus can be used as interchangeable therapeutic agents in chickens.
\end{abstract}

Keywords: Bioavailability; Bioequivalence; Broiler; Chicken; Enrofloxacin; Intracrop; Intravenous; Pharmacokinetics.

\section{Introduction}

It is overt that the cost of developing a new drug has been escalating globally during the last decades, and this has prompted efforts in most countries to reduce that cost. Along this, the concepts of bioavailability (BA) and bioequivalence (BE) have gained considerable importance because they have become the cornerstones for the approval of generic drugs globally and have been utilized to reduce cost of drug development (Midha and McKay 2009).

The FDA formulated regulations for the submission of BA and BE data. These regulations are incorporated in the $21^{\text {st }}$ volume of Code of Federal Regulation, Part 320 (21CFR320) (FDA 2015). On the top of these regulations, FDA stated some scientific definitions to apply in BE studies. Bioavailability (F) means the rate and extent to which the active ingredient or active moiety is absorbed from a drug product and becomes available at the site of action. Bioequivalence means the absence of a significant difference in the rate and extent to which the active ingredient or active moiety in pharmaceutical equivalents or pharmaceutical alternatives becomes available at the site of drug action when administered at the same molar dose under similar conditions in an appropriately designed study. Bioequivalence requirement means a requirement imposed by the FDA for in vitro and/or in vivo testing of specified drug products which must be satisfied as a condition of marketing. The requirement or regulatory limits applied are that the $90 \%$ confidence intervals for the ratios of the areas under the drug concentration versus time curves (AUC ratio) and the maximum plasma drug concentrations $\left(\mathrm{C}_{\max }\right.$ ratio) must fall between $80 \%$ and $125 \%$. The times to maximum plasma concentration $\left(\mathrm{T}_{\max }\right)$ for both products should also be similar. These requirements for similarity between the two products are therefore in both the extent of absorption (AUC ratio) and the rate of absorption $\left(\mathrm{C}_{\max }\right.$ and $\mathrm{T}_{\max }$ ratios). For other pharmacokinetic parameters, considerations analogous to those for AUC, $\mathrm{C}_{\max }$ or $\mathrm{T}_{\max }$ apply, taking into consideration the use of log-transformed or untransformed data, respectively.

The European Medicines Agency (EMA) in London released also almost similar regulations regarding bioequivalence studies and approval of generic products (EMA 2010).

The term 'generic product' used by the WHO for a pharmaceutical product that is: (i) intended to be interchangeable with the innovator product in an individual patient, (ii) usually manufactured without a licence from the innovator company, and (iii) marketed after expiry of patent or other exclusivity rights. The WHO refers to these products as 'multisource pharmaceutical products'. To be interchangeable such products must be bioequivalent (Birkett 2003).

Enrofloxacin (ENRO, Figure 1), is a fluoroquinolone that was developed exclusively for veterinary use in many animal species including, cattle, pigs, dogs, cats... etc. (Altreuther 1987); and for the treatment of respiratory disease in chickens and turkeys 
(Anderson et al. 2003). After administration, ENRO is partly deethylated to ciprofloxacin in vivo, which is also pharmacologically active and is employed in human medicine (Rao et al. 2002). Although FDA withdrew the approval for ENRO for the purpose of treating bacterial infections in poultry because of scientific data that showed that the use of ENRO in poultry caused resistance to Campylobacter, a bacterium that causes foodborne illness (FDA 2005). However, in many developing countries, ENRO is still being used as a routine choice to treat almost any bacterial disease in poultry.

Like all members of fluoroquinolones, ENRO produces its antimicrobial action in multiple species of bacteria via damage of bacterial DNA leading to defects in negative supercoiling. This effect was linked to inhibition of DNA gyrase activity, an enzyme found in all bacteria (Gellert et al. 1977).

The original preparation of ENRO was produced by Bayer ${ }^{\circledR}$ Corporation, Animal Health Division (Barmen, Germany) under the trade name of Baytril ${ }^{\circledR}$ of different pharmaceutical formulations However, nowadays, there are many generic preparations of ENRO marketed in the veterinary medical field and not all preparations give the same desired effects and safety levels; and as the potential non-equivalence of a drug preparation has been a matter of pharmacological concern, therefore, the aim of the present study is to compare, from the pharmacokinetic endpoint of view, between two ENRO 10\% oral solution preparations, namely, Enrol $^{\circledR}\left(\right.$ Medmac $^{\circledR}$, Amman, Jordan) as ENRO-A and Syvaquinol ${ }^{\circledR}$ (Syva ${ }^{\circledR}$, Leon, Spain) as ENRO-B, that are widely distributed in the veterinary drug market for broiler industry.

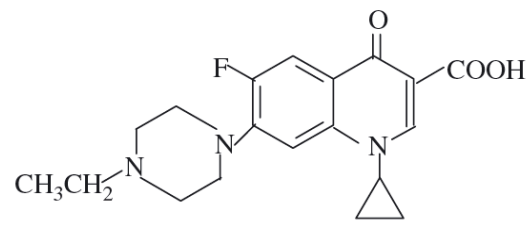

Fig. 1: Structural Formula of Enrofloxacin.

\section{Material \& methods}

\subsection{Drugs}

ENRO occurs as a pale yellow crystalline powder slightly soluble in water at $\mathrm{pH}=7$, soluble in potassium hydroxide, glacial acetic acid, ethanol, $0.1 \mathrm{M}$ hydrochloric acid, $0.1 \mathrm{M}$ sodium hydroxide (Heitzman 1997). ENRO has the molecular formula $\mathrm{C}_{19} \mathrm{H}_{22} \mathrm{FN}_{3} \mathrm{O}_{3}$ (Figure 1), the chemical Name: 1-cyclopropyl-7-(4-ethyl-1piprazinyl)-6-fluoro-1, 4-dihydro-4-oxo-3-quinoline carboxylic acid; and molecular weight: $359.39 \mathrm{~g} / \mathrm{mole}$.

Three types of ENRO were used in the present study: the standard ENRO base (purity $98.00 \%$ ) was obtained as crystalline powder from Sigma-Aldrich ${ }^{\circledR}$ Corporation (St. Louis, USA). It was used for standardization of calibration curve in HPLC and for i.v. experiment. Two generic ENRO oral preparations were obtained from our local drug market as $10 \%$ solutions. Brand-A was Enrol ${ }^{\circledR}$ 10 oral solution, which contains ENRO at concentration of 100 $\mathrm{mg} / \mathrm{mL}$; the preparation is a product of Medmac ${ }^{\circledR}$ (Amman, Jordan), Batch: v120804. While Brand-B was Syvaquinol ${ }^{\circledR} 10 \%$ oral solution, which also contains ENRO at concentration of 100 $\mathrm{mg} / \mathrm{mL}$; the preparation is a product of $\operatorname{Syva}^{\circledR}$ (Leon, Spain); Batch: 301216.

\subsection{Experimental animals and design}

Twenty four clinically healthy Ross broiler chickens were used. Animals were numbered and accommodated in a suitable pen under hygienic condition with controlled temperature $\left(22 \pm 1^{\circ} \mathrm{C}\right)$, humidity $(60 \pm 10 \%)$ and light $(12 \mathrm{~h}$ per day) for at least a week before being used. Food and water were available ad libitum. Feed was withdrawn 12 hours before drug administration to avoid ab- sorption variability due to possible ENRO-feed interaction. Water was withdrawn 2 hour to minimize variation in stomach empting or degree of ENRO. The chickens were weighed prior to experiment for dose adjustment using an ordinary balance (San sheng ${ }^{\circledR}$ scales, Taiwan); the average body weight was $2.5 \mathrm{Kg}$.

The experiment was designed in a parallel manner where the chickens were grouped randomly as follows:

Group (I): included 6 chickens; each bird was injected intravenously (i.v.) into the wing vein with $10 \mathrm{mg} / \mathrm{Kg}$ body weight of the standard ENRO for pharmacokinetic analysis.

Group (II): included 6 chickens; each bird was orally (i.c.) administered a single dose of $10 \mathrm{mg} / \mathrm{Kg}$ body weight of ENRO $10 \%$ (Brand-A) for pharmacokinetic comparison.

Group (III): included 6 chickens; each bird was orally (i.c.) administered a single dose of $10 \mathrm{mg} / \mathrm{Kg}$ body weight of ENRO $10 \%$ (Brand-B) for pharmacokinetic comparison.

The rest of birds were kept untreated for collecting clear plasma for preparing standard concentrations of calibration curve of $\mathrm{EN}$ RO in HPLC analysis.

\subsection{Drug preparation and administration}

The recommended dose of ENRO in poultry is $10 \mathrm{mg} / \mathrm{Kg}$ body weight by various routes of administration. For i.v. phase of the experiment, an injectable solution $(30 \mathrm{mg} / \mathrm{ml})$ of the standard EN$\mathrm{RO}$ was prepared in $0.1 \mathrm{M}$ of sodium hydroxide solution according to Heitzman (1997). Each of the two commercial oral preparations was already formulated as ENRO $10 \%(100 \mathrm{mg} / \mathrm{mL})$. Experimentally, an oral solution of ENRO $1 \%(10 \mathrm{mg} / \mathrm{mL})$ of both preparations (A) and (B) was prepared by adding $1.0 \mathrm{~mL}$ of the corresponding stock solution of ENRO $10 \%$ to $9.0 \mathrm{~mL}$ of bidistilled water. Administration via i.v. route was performed using a syringe with $22 \mathrm{G}$ needle into the wing vein; while administration via oral route was performed using a syringe with plastic cannula to deliver the drug solution i.c.

\subsection{Sampling}

About two $\mathrm{mL}$ of blood were collected from wing and metatarsal veins at $0.083,0.176,0.25,0.5,1,2,4,6,8,12$ and 24 hours after single i.v. bolus administration and at $0.5,1,2,4,6,8,12$ and 24 hours after the single i.c. administration. Collection was performed in lithium-heparinized tubes; each tube was properly labelled with the given number of particular chicken and time of sampling. The samples were centrifuged at $3000 \mathrm{rpm}$ for 10 minutes and the separated plasma were transferred to labelled Eppendorf tubes and kept frozen at $-50^{\circ} \mathrm{C}$ until the time of assay.

\subsection{Enrofloxacin assay}

The concentrations of ENRO in plasma were determined using HPLC technique with UV detection according to the method described by Küng et al. (1993), after ENRO extraction from plasma according to Nielsen and Gyrd-Hansen (1997) with minor modifications. The assay was accomplished by the following steps:

i) Standard calibration curve

The calibration curves of plasma were prepared with six serial concentrations ranging between 0.0 and $8 \mu \mathrm{g} / \mathrm{mL}$ using blank chicken plasma. ENRO standard substance equivalent to $10 \mathrm{mg}$ of ENRO was accurately weighed and transferred to a $10 \mathrm{~mL}$ volumetric flask. One $\mathrm{mL}$ methanol was added and then blank plasma to make up volume to $10 \mathrm{~mL}$ in order to give a final concentration of $1 \mathrm{mg} / \mathrm{mL}$. From this solution, the stock concentration of 8 $\mu \mathrm{g} / \mathrm{mL}$ in blank plasma was prepared and aliquots of this stock were diluted with the blank plasma to obtain various concentrations of $4,2,1$ and $0.5 \mu \mathrm{g} / \mathrm{mL}$, which were assayed by HPLC using the method described below (the same method followed for samples). ENRO-free plasma was used as blank $(0.0 \mu \mathrm{g} / \mathrm{mL})$. A calibration curve was obtained by plotting the peak heights versus the nominal concentrations. The equation was calculated by the least-squares method using linear regression. 
ii) Sample preparation for chromatography

To $200 \mu \mathrm{l}$ of calibration or experimental plasma aliquots, $300 \mu \mathrm{l}$ of acetonitrile were added in glass centrifuge tubes. The tubes were shaken at high speed for 10 seconds by vortex-mix $\left(\right.$ FALC $^{\circledR}$ instruments, Treviglio, Italy). After centrifuging for $10 \mathrm{~min}$. at $1500 \mathrm{rpm}$ (Hamilton Bell ${ }^{\circledR}$, New Jersey, USA) at room temperature, $400 \mu 1$ of the supernatant was transferred to new tubes and mixed with twice volume $(800 \mu \mathrm{l})$ of bi-distilled water to yield 1.2 $\mathrm{ml}$ volume. The previous mixture was filtered by a syringe membrane filter of $0.45 \mu \mathrm{m}$ pore size and the used for HPLC-analysis.

iii) HPLC system and its conditioning

The liquid chromatographic system used in the present study was Knauer $^{\circledR}$ (Berlin, Germany) consisted of a pump (Smartline Pump 1000 ) with solvent delivery module (Smartline Manager 5000) equipped with an autosampler (Smartline Autosampler 3950), analytical column (Eurospher 100-5 C18; $250 \times 4.6 \mathrm{~mm}$ ) with a thermostat (Smartline Column Thermostat; from 5 to $85{ }^{\circ} \mathrm{C}$ ) and a variable wavelength ultraviolet detector (Smartline UV Detector 2600). ChromGate ${ }^{\circledR}$ v. 3.3.2 chromatography software was used for data acquisition, data reporting and analysis. The isocratic mobile phase consisted of bi-distilled water $80 \%$, methanol $3 \%$ (Scharlau ${ }^{\circledR}$ chemie S. A, Sentmental, Spain) and acetonitrile $17 \%$ (Merk $^{\circledR} \mathrm{KGaA}$, Dromstadt, Germany) with $0.4 \%$ orthophosphoric acid $\left(\mathrm{BDH}^{\circledR}\right.$ laboratory supplies, Poole, England) and $0.4 \%$ triethylamine (Merk ${ }^{\circledR}$, Schuchardt OHG, Hohenbrunn, Germany). $\mathrm{PH}$ of the mobile phase was adjusted to 3 by triethylamine. The flow rate was $1 \mathrm{ml} / \mathrm{min}$ at room temperature; the sample injection volume was $20 \mu \mathrm{l}$; and the detector wavelength was set at $278 \mathrm{~nm}$. Under these conditions, the retention times for ENRO was 5.5 6.1 min and thus run time was adjusted at $10 \mathrm{~min}$. All plasma samples taken from each animal were analysed in the same chromatographic run (analytical own control). Each run had a separate daily calibration.

\subsection{Pharmacokinetic analysis}

The plasma concentration vs time (C-T) data of each bird after i.v. and i.c. administrations of ENRO $(10 \mathrm{mg} / \mathrm{Kg}$ as single dose boluses) were analysed using non-compartmental analysis with the aid of the computer program WinNonLin v. 5.3 (Pharsight ${ }^{\circledR}$ Corporation, A Certara Company, St. Louis, USA) based on the equations derived originally by Gibaldi and Perriere (2007) as described below. Pharmacokinetic parameters were calculated individually for each animal, and presented as Mean \pm SEM of 6 observations. Non-compartmental analysis is preferred in clinical pharmacokinetic studies that are frequently designed to identify and quantify any effects of certain conditions on the main pharmacokinetic parameters of a drug: clearance, volume of distribution, bioavailability, and half-life, rather than determining the pharmacokinetic parameters by trying to fit the data to compartmental models. The factor that was targeted here is the quality of formulation of the two different ENRO brands.

\section{i) Intravascular kinetics}

The value of $\lambda$ was determined as the (- slope) of $L n C_{p}$ vs time curve for the last 3-5 data points of elimination phase and obtaining the "constant B" value by back extrapolation. The value of $\lambda$ was based on the following equation:

Slope $=\frac{\ln \mathrm{y}_{2}-\ln \mathrm{y}_{1}}{\mathrm{x}_{2}-\mathrm{x}_{1}} \quad \stackrel{\text { yields }}{\longrightarrow} \quad \lambda=-\frac{\ln \mathrm{C}_{\text {late } 2}-\ln \mathrm{C}_{\text {late } 1}}{\mathrm{t}_{\text {late } 2}-\mathrm{t}_{\text {late } 1}} \quad\left(\mathrm{~h}^{-1}\right)$

Then $t_{1 / 2(\lambda)}$ was calculated as:

$\mathrm{t} 1 / 2(\lambda)=\frac{0.693}{\lambda}$

The total area under the plasma concentration-time curve (AUC), also called zero moment curve gives the term of the total amount of the drug in the body. It is useful in calculating bioavailability. It is calculated on the basis of the trapezoidal rule as follows:
$\mathrm{AUC}_{0 \rightarrow \infty}=\frac{\mathrm{C}^{\circ}+\mathrm{C}^{1}}{2}\left(\mathrm{t}_{1}-\mathrm{t}_{0}\right)+\frac{\mathrm{C}^{1}+\mathrm{C}^{2}}{2}\left(\mathrm{t}_{2}-\mathrm{t}_{1}\right)+$
$\frac{\mathrm{C}^{2}+\mathrm{C}^{3}}{2}\left(\mathrm{t}_{3}-\mathrm{t}_{2}\right)+\cdots \frac{\mathrm{C}^{\text {last }}}{\lambda} \quad(\mathrm{mg} \cdot \mathrm{h} / \mathrm{L})$

The first moment curve was depicted in terms of "concentration $x$ time" versus "time". The area under the first moment curve (AUMC) was calculated by the trapezoidal rule but with replacing $\mathrm{C}_{\mathrm{p}}$ by $\mathrm{C}_{\mathrm{p}}{ }^{*} \mathrm{t}$ as follows:

$\mathrm{AUMC}_{0 \rightarrow \infty}=\frac{\mathrm{C}^{\circ} \mathrm{t}_{0}+\mathrm{C}^{1} \mathrm{t}_{1}}{2}\left(\mathrm{t}_{1}-\mathrm{t}_{0}\right)+\frac{\mathrm{C}^{1} \mathrm{t}_{1}+\mathrm{C}^{2} \mathrm{t}_{2}}{2}\left(\mathrm{t}_{2}-\mathrm{t}_{1}\right)+$
$\frac{\mathrm{C}^{2} \mathrm{t}_{2}+\mathrm{C}^{3} \mathrm{t}_{3}}{2}\left(\mathrm{t}_{3}-\mathrm{t}_{2}\right)+\cdots+\frac{\mathrm{Clast}^{\text {last }}}{\lambda}+\frac{\mathrm{C}^{\text {last }}}{\lambda^{2}} \quad \mathrm{mg} \cdot \mathrm{h}^{2} / \mathrm{L}$

It should be noted that AUMC is expressed in terms of $\mathrm{mg} \cdot \mathrm{h}^{2} / \mathrm{L}$ unlike AUC is expressed in terms of mg.h/L.

The mean residence time (MRT) represents the average time the drug molecules reside in the body following the administration of a single i.v. dose. It is expressed as the ratio of AUMC to AUC as follows:

MRT $=\frac{\text { AUMC }}{\text { AUC }}$

The mean elimination rate constant $\left(\mathrm{K}_{\mathrm{el}}\right)$ and mean elimination Half-life $\left(\mathrm{t}_{1 / 2 \mathrm{el}}\right)$ represent the overall elimination rate constant $\left(\mathrm{K}_{\mathrm{el}}\right)$ and half-life $\left(\mathrm{t}_{1 / 2 \mathrm{el}}\right)$ in terms of MRT as follows:
$\mathrm{K}_{\mathrm{el}}=\frac{1}{\mathrm{MRT}}$
$\mathrm{t}_{1 / 2 \mathrm{el}}=0.0693 * \mathrm{MRT}_{\mathrm{iv}}$

The volume of distribution $\left(\mathrm{V}_{\mathrm{d}}\right)$ of a drug is a ratio of the amount of drug in the body at any time to the plasma concentration at that time. At steady state, there is an equilibrium between the loss of drug from elimination and the gain of drug from administration. The statistical moment theory can calculate the volume of distribution at steady state $\left(\mathrm{V}_{\mathrm{d}(\mathrm{ss})}\right)$ on the basis of following equation:

$\mathrm{V}_{\mathrm{d}(\mathrm{ss})}=\frac{\mathrm{D} * \mathrm{MRT}}{\mathrm{AUC}}$

Clearance of a drug from the body $\left(\mathrm{Cl}_{\mathrm{B}}\right)$ can be expressed in terms of the volume of blood cleared of the drug by the various elimination processes (biotransformation and excretion) per unit time and body weight. It represents the sum of all clearance processes. Therefore, clearance is a measure of the ability of the organs of elimination to remove drug from the plasma, and it is a constant of proportionality between the rate of elimination at any time and the corresponding plasma concentration. It was calculated on the basis of the following equation:

$$
\mathrm{Cl}_{\mathrm{B}}=\frac{\mathrm{D}}{\mathrm{AUC}} \quad(\mathrm{L} / \mathrm{h} / \mathrm{Kg})
$$

ii) Intracrop kinetics

In this occasion, absorption or access of the drug to the blood from its site of administration occurs. The process of absorption brings additional parameters that could be calculated such parameters are the absorption rate constant $\left(\mathrm{K}_{\mathrm{ab}}\right)$, absorption half-life $\left(\mathrm{t}_{1 / 2 \mathrm{ab}}\right)$, mean absorption time (MAT), mean transient time (MTT), the maximum concentration $\left(\mathrm{C}_{\max }\right)$, the time to reach maximum concentration $\left(\mathrm{T}_{\max }\right)$ and the bioavailability $(\mathrm{F})$.

The mean absorption time (MAT) was calculated for extravascular routes of administration on the basis of the following equation:

MAT $=$ MRT $_{\text {ic }}-$ MRT $_{\text {iv }}$

Mean transit time (MTT) is the time taken by drug molecules after extravascular administration to pass through the body. It is the sum of the absorption time and the residence time: 
$\mathrm{MTT}=\mathrm{MAT}_{\mathrm{ic}}+\mathrm{MRT}_{\mathrm{ic}}$

The absorption rate constant $\left(\mathrm{K}_{\mathrm{ab}}\right)$ was calculated in terms of MAT on the basis of the following equation:

$\mathrm{K}_{\mathrm{ab}}=\frac{1}{\mathrm{MAT}}$

Apparent volume of distribution $\left(\mathrm{V}_{\mathrm{d}}\right)$, here, represents the overall total volume of distribution which describes the ratio of the total amount of the drug in the body to the plasma concentration at the terminal phase; it was calculated automatically on the basis of the next equation:

$\mathrm{V}_{\mathrm{d}}=\frac{\mathrm{F} * \mathrm{D}}{\mathrm{AUC}_{\text {(ic) }}} / \lambda$

Total body clearance $\left(\mathrm{Cl}_{\mathrm{B}}\right)$, here, represents the overall clearance of the drug from the body and was expressed in terms of the volume of blood cleared of the drug by the body per unit time and body weight. It was calculated automatically on the basis of the next equation:

$\mathrm{Cl}_{\mathrm{B}}=\frac{\mathrm{F} * \mathrm{D}}{\mathrm{AUC}_{(\mathrm{ic})}}(\mathrm{L} / \mathrm{h} / \mathrm{Kg})$

Maximum concentration $\left(\mathrm{C}_{\max }\right)$ and Time to maximum concentration $\left(\mathrm{T}_{\max }\right)$ represent the peak plasma concentration a drug reaches in plasma and the time to reach that peak. They were directly taken from the Concentration-Time data table for each drug preparation.

Bioavailability (F \%) represents the fraction of a drug from a dosage form that reaches intact to the systemic circulation. It is determined by comparing the area under the plasma C-T curve following a single i.c. administration $\left(\mathrm{AUC}_{\mathrm{i} . \mathrm{c} .}\right)$ with that following i.v. injection $\left(\mathrm{AUC}_{\mathrm{i} . \mathrm{v}}\right)$ in the same bird. It was calculated on the basis of the following equation:

$\mathrm{F}=\frac{\mathrm{AUC}_{(\mathrm{ic})}}{\mathrm{AUC}_{(\mathrm{iv})}} \times 100(\%)$

\subsection{Statistical analysis}

HPLC analysis of ENRO standard concentrations were done as triplicates. Concentrations of ENRO in time point plasma samples were calculated as Mean \pm SEM of six observations $(n=6)$ and C$\mathrm{T}$ tables and graphs were designed using these values. Each pharmacokinetic parameter was calculated for every individual bird; and the final data were expressed as Mean \pm SEM of 6 observations $(n=6)$ in each experimental group (single i.v. bolus; single i.c. bolus of ENRO-A; and single i.c. bolus of ENRO-B) included in the study. Superiority between the ENRO-A and ENRO-B was determined using Student's $t$-test with significance set at $p \leq 0.05$. All statistical procedure were done using SPSS v. 20 software.

\section{Results}

No clinical toxicity symptoms appeared on ENRO-administered birds. Just only some drowsiness for a few seconds was observed after i.v. administration. The obtained results of calibration, i.v. standard ENRO, i.c. ENRO-A and i.c. ENRO-B as well as comparison between both brands were tabulated and graphed as follows.

\subsection{Standard calibration curve}

Figs. 2, 3, 4 and 5 are examples of the recorded chromatograms showing the concentration-dependent, escalating peaks of absorbance (indicated by arrows) of the standard concentrations (1, 2, 4 $\& 8 \mu \mathrm{g} / \mathrm{mL}$ ) of ENRO in drug-free broiler chicken plasma. Fig. 6 shows the standard curve of ENRO in drug-free plasma obtained by depicting all used concentrations from 0.0 to $8 \mu \mathrm{g} / \mathrm{mL}$.

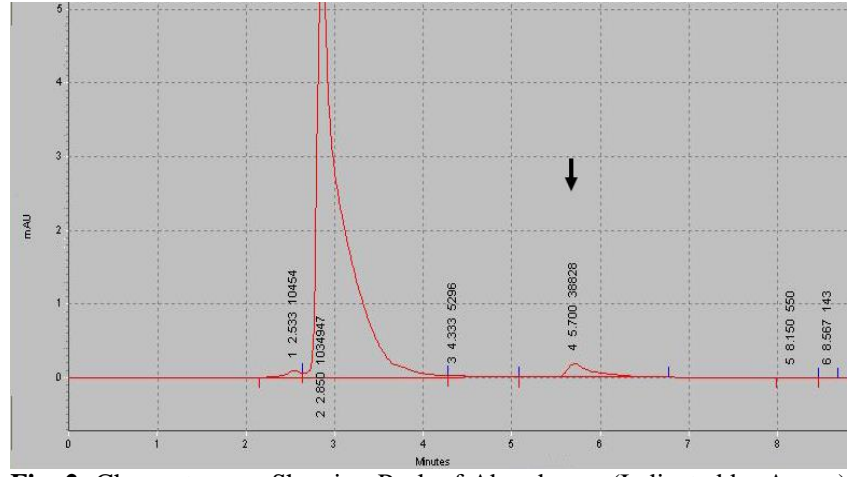

Fig. 2: Chromatogram Showing Peak of Absorbance (Indicated by Arrow) of the Standard Concentration $(1 \mu \mathrm{g} / \mathrm{mL})$ of ENRO in Drug -Free Broiler Chicken Plasma.

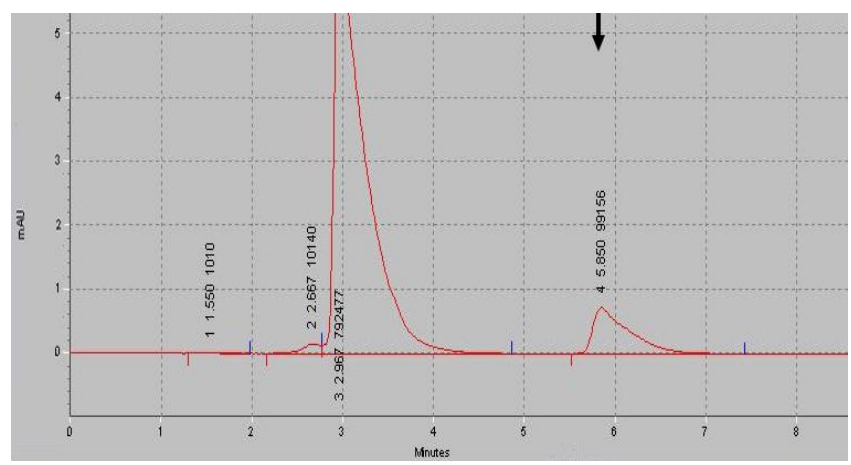

Fig. 3: Chromatogram Showing Peak of Absorbance (Indicated by Arrow) of the Standard Concentration $(2 \mu \mathrm{g} / \mathrm{mL})$ of ENRO in Drug-Free Broiler Chicken Plasma.

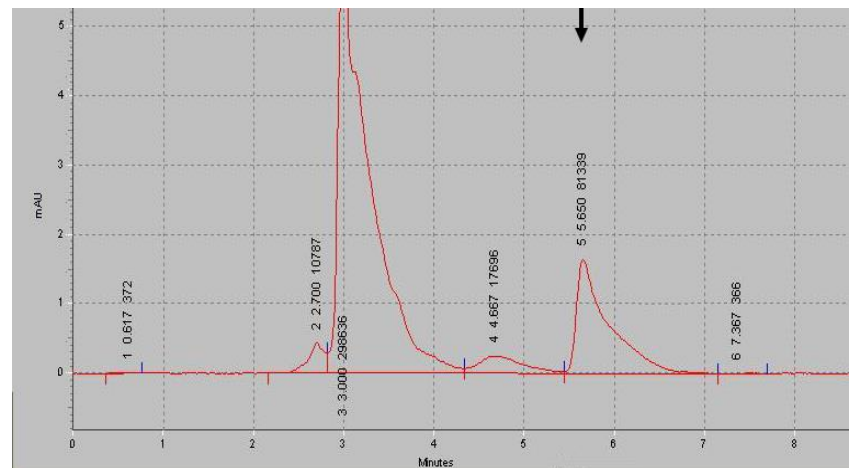

Fig. 4: Chromatogram Showing Peak of Absorbance (Indicated by Arrow) of the Standard Concentration $(4 \mu \mathrm{g} / \mathrm{mL})$ of ENRO in Drug-Free Broiler Chicken Plasma.

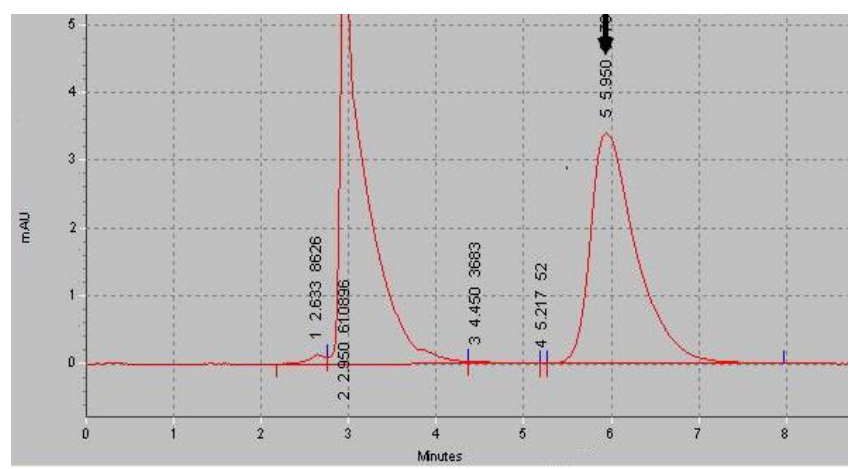

Fig. 5: Chromatogram Showing Peak of Absorbance (Indicated by Arrow) of the Standard Concentration $(8 \mu \mathrm{g} / \mathrm{mL})$ of ENRO in Drug-Free Broiler Chicken Plasma.

\subsection{Plasma concentrations}

Mean \pm SEM values of plasma concentration $(\mu \mathrm{g} / \mathrm{mL})$ of ENRO following single i.v. (Standard) and i.c. (ENRO-A and ENRO-B) bolus administrations at dose rate of $10 \mathrm{mg} / \mathrm{Kg}$ body weight in broiler chickens $(n=6)$ are shown in Fig. 7 . 


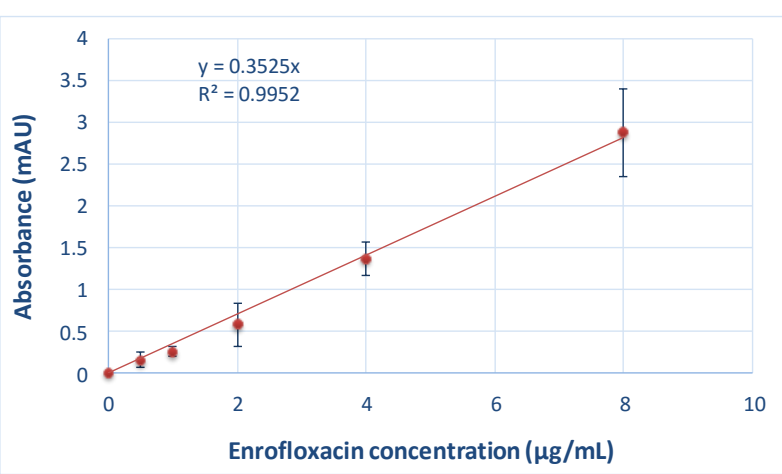

Fig. 6: Histogram Showing Standard Curve of ENRO in Drug-Free Broiler Chicken Plasma. Values are Expressed as Means and Standard Errors of the Means of Triplicates.

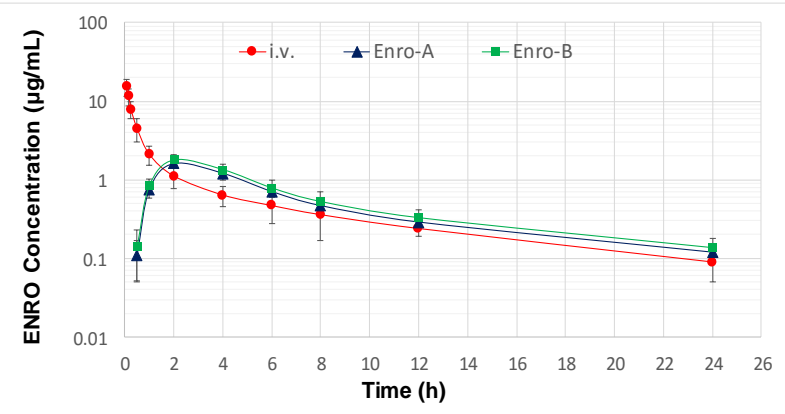

Fig. 7: Semi-logarithmic Graph Showing Plasma Concentrations (Mean \pm SEM) of Standard ENRO, Brand-A (ENRO-A) and Brand-B (ENRO-B) in Broiler Chickens Following A Single i.v. (Standard) and i.c. (A or B) Bolus Administrations of $10 \mathrm{mg} / \mathrm{Kg}$ Body Weight, Respectively, $(n=6)$.

\subsection{Pharmacokinetic parameters}

Pharmacokinetic parameters of ENRO in broiler chickens following single i.v. bolus of Standard ENRO administration of 10 $\mathrm{mg} / \mathrm{Kg}$ body weight are listed in Table 2 and its WinNonLin noncompartmental analytical graph was shown in Fig. 8.

Table 2: Pharmacokinetic Parameters of Standard ENRO in Broiler Chickens Following A Single i.v. Bolus Administration of $10 \mathrm{mg} / \mathrm{Kg}$ B. W. $(n=6)$.

\begin{tabular}{|c|c|c|c|}
\hline \multirow{2}{*}{$\begin{array}{l}\text { Parameter (unit) } \\
\lambda\left(\mathrm{hr}^{-1}\right)\end{array}$} & \multicolumn{3}{|c|}{ Value (Mean \pm SEM) } \\
\hline & 0.0855 & \pm & 0.006 \\
\hline $\mathrm{T}^{1} / 2_{\lambda}(\mathrm{hr})$ & 8.1060 & \pm & 0.835 \\
\hline $\mathrm{C}^{\circ}(\mathrm{mg} / \mathrm{L})$ & 20.103 & \pm & 2.811 \\
\hline AUC (mg.hr/L) & 16.139 & \pm & 2.230 \\
\hline $\operatorname{AUMC}\left(\mathrm{mg} \cdot \mathrm{hr}^{2} / \mathrm{L}\right)$ & 99.012 & \pm & 10.33 \\
\hline MRT (hr) & 6.1349 & \pm & 0.305 \\
\hline $\mathrm{K}_{\mathrm{el}}\left(\mathrm{hr}^{-1}\right)$ & 0.1630 & \pm & 0.023 \\
\hline $\mathrm{T} 1 / 2 \mathrm{el}(\mathrm{hr})$ & 4.2515 & \pm & 0.130 \\
\hline $\mathrm{V}_{\mathrm{d}(\mathrm{ss})}(\mathrm{L} / \mathrm{Kg})$ & 3.8012 & \pm & 0.193 \\
\hline $\mathrm{Cl}_{\mathrm{B}}(\mathrm{L} / \mathrm{hr} / \mathrm{Kg})$ & 0.6196 & \pm & 0.073 \\
\hline
\end{tabular}

Pharmacokinetic parameters of ENRO in broiler chickens following single i.c. $10 \mathrm{mg} / \mathrm{Kg}$ body weight bolus of ENRO-A or ENRO-B administration are tabulated in Table 3 and their WinNonLin non-compartmental analytical graphs were shown in Figs. $9 \& 10$.

\section{Discussion}

Quinolones comprise a large and expanding group of synthetic antimicrobial agents. The first drug of this class, nalidixic acid that was discovered in 1962 as a byproduct of chloroquine (antimalarial) in 1962 (Lesher et al. 1962) and was approved for clinical use in 1965. However, its antibacterial spectrum of activity was restricted to the Enterobacteriaceae and, because of limita- tions in absorption and distribution, the drug was effective solely for the treatment of urinary tract infections.

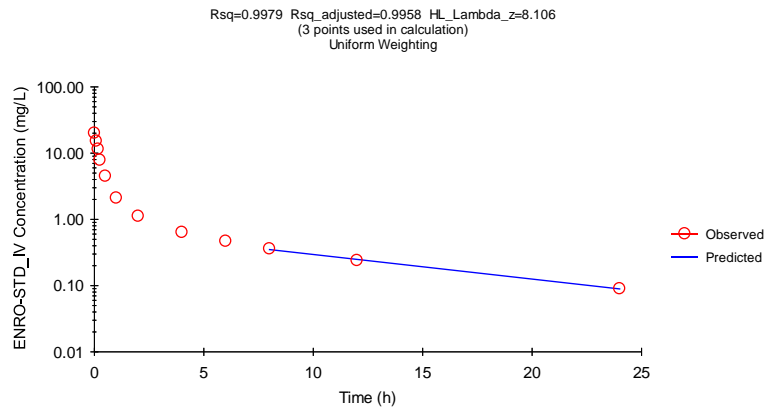

Fig. 8: WinNonLin Semi-logarithmic Plot Used for Non-compartmental Analysis of Standard ENRO Following Single i.v. Bolus Administration to Broilers at Dose Rate of $10 \mathrm{mg} / \mathrm{Kg}$ Body Weight (Medium Value as An Example).

Table 3: Comparative Table of Pharmacokinetic Profiles (Mean \pm SEM) Between ENRO-A and ENRO-B in Broiler Chickens Following A Single i.c. Bolus Administration of $10 \mathrm{mg} / \mathrm{Kg}$ Body Weight $(n=6$; Noncompartmental Analysis; WinNonLin).

\begin{tabular}{|c|c|c|c|c|c|c|}
\hline Parameter (unit) & \multicolumn{3}{|c|}{ ENRO-A } & \multicolumn{3}{|c|}{ ENRO-B } \\
\hline$\lambda\left(\mathrm{hr}^{-1}\right)$ & 0.0826 & \pm & 0.005 & 0.0819 & \pm & 0.004 \\
\hline $\mathrm{T}^{1} / 2 \lambda(\mathrm{hr})$ & 8.3910 & \pm & 0.312 & 8.4583 & \pm & 0.906 \\
\hline $\mathrm{C}_{\max }(\mathrm{mg} / \mathrm{L})$ & 1.6100 & \pm & 0.203 & 1.7900 & \pm & 0.283 \\
\hline $\mathrm{T}_{\max }(\mathrm{h})$ & 2.0000 & \pm & 0.000 & 2.0000 & \pm & 0.000 \\
\hline MRT (hr) & 10.306 & \pm & 0.805 & 10.430 & \pm & 1.935 \\
\hline MAT (hr) & 4.1712 & \pm & 0.215 & 4.2952 & \pm & 0.505 \\
\hline MTT (hr) & 14.477 & \pm & 1.202 & 14.725 & \pm & 2.915 \\
\hline $\mathrm{K}_{\mathrm{ab}}\left(\mathrm{hr}^{-1}\right)$ & 0.2397 & \pm & 0.043 & 0.2328 & \pm & 0.033 \\
\hline $\mathrm{K}_{\mathrm{el}}\left(\mathrm{hr}^{-1}\right)$ & 0.0970 & \pm & 0.006 & 0.0959 & \pm & 0.005 \\
\hline AUC (mg.hr/L) & 12.744 & \pm & 2.951 & 14.354 & \pm & 2.851 \\
\hline $\operatorname{AUMC}\left(\mathrm{mg} \cdot \mathrm{hr}^{2} / \mathrm{L}\right)$ & 131.34 & \pm & 12.73 & 149.72 & \pm & 15.21 \\
\hline $\mathrm{F}(\%)$ & 78.960 & \pm & 6.728 & 88.940 & \pm & 10.89 \\
\hline $\mathrm{V}_{\mathrm{d}}(\mathrm{L} / \mathrm{Kg})$ & 7.5006 & \pm & 0.781 & 7.5609 & \pm & 0.995 \\
\hline $\mathrm{Cl}_{\mathrm{B}}(\mathrm{L} / \mathrm{hr} / \mathrm{Kg})$ & 0.6195 & \pm & 0.164 & 0.6196 & \pm & 0.177 \\
\hline
\end{tabular}

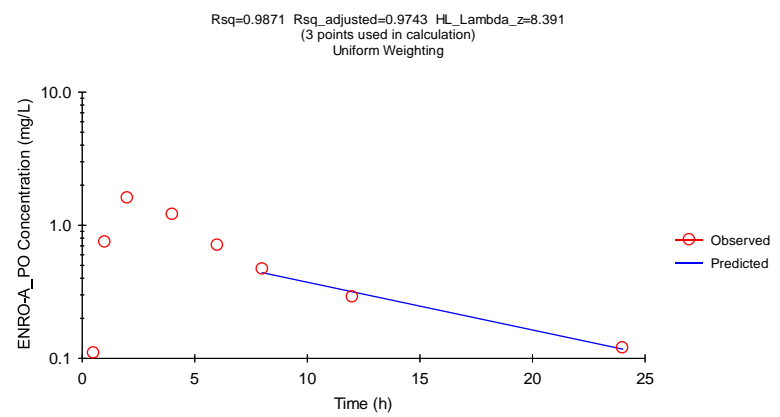

Fig. 9: WinNonLin Semi-logarithmic Plot Used for Non-compartmental Analysis of ENRO-A Following Single i.c. Bolus Administration to Broilers at Dose Rate of $10 \mathrm{mg} / \mathrm{Kg}$ Body Weight (Medium Value as An Example).

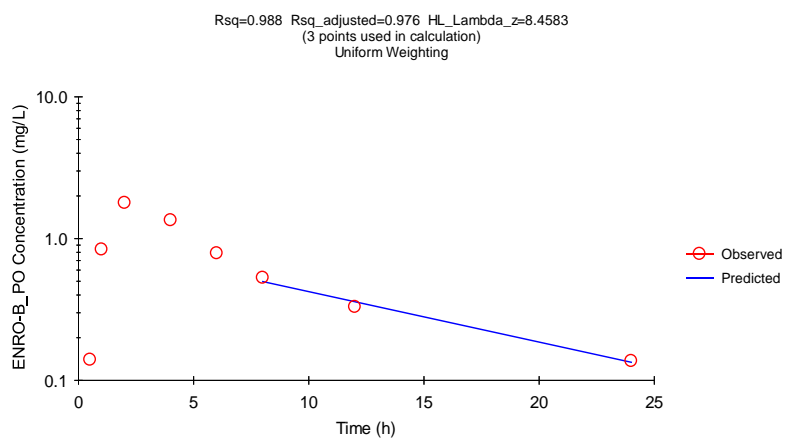

Fig. 10: WinNonLin Semi-logarithmic Plot Used for Non-compartmenta Analysis of ENRO-B Following Single i.c. Bolus Administration to Broilers at Dose Rate of $10 \mathrm{mg} / \mathrm{Kg}$ Body Weight (Medium Value as an Example). 
In the 1980s, the addition both of a fluorine molecule at the 6 position of the basic quinolone structure and a piperazine substitution at the 7-position was found to enhance quinolone antibacterial activity, gaining effectiveness against such organisms as Pseudomonas aeruginosa and Gram-positive cocci, and to increase the extent of oral drug absorption and tissue distribution (Ball 2000). Products possessing this fluorine molecule are known as the fluoroquinolones.

Generally, on the basis of historical and the antimicrobial properties points of view, quinolones may be classified into three generations. The $1^{\text {st }}$ generation comprises the original quinolone compounds such as nalidixic acid, oxolinic acid, pipemidic acid and cinoxacin that were first discovered in 1960s. These molecules were associated with poor oral bioavailability, limited distribution into systemic tissues, and a spectrum of activity limited to Escherichia coli and several other Gram-negative organisms.

The $2^{\text {nd }}$ generation quinolones (fluoroquinolones), were developed in the 1980s, exhibited increased antibacterial activity against the Enterobacteriaceae and other Gram-negative bacteria (such as $P$. aeruginosa), and had some activity against certain Gram-positive cocci in addition. Structural changes associated with the $2^{\text {nd }}$ generation increased their oral bioavailability and systemic distribution. They include norfloxacin, ciprofloxacin, enrofloxacin, danofloxacin, difloxacin and marbofloxacin.

The $3^{\text {rd }}$ generation drugs maintained the favorable characteristics of the $2^{\text {nd }}$ generation drugs while exhibiting increased activity against Gram-positive bacteria, anaerobes and Mycobacteria These compounds also exhibited excellent oral bioavailability and were associated with a prolonged terminal elimination half-life They include gatifloxacin, trovafloxacin and moxifloxacin. The $3^{\text {rd }}$ generation fluoroquinolones have lower central nervous system toxicities and exhibit fewer interactions with the cytochrome P450 (CYP 450) system (Ball 2000).

Some pharmacologists, however, prefer to classify quinolones into 4 generations not only three depending on their structure-activity (as well as -toxicity) relationships and other factors (Van Bambeke et al. 2005). The $4^{\text {th }}$ generation was exemplified by garenoxacin.

ENRO (Figure 1), is a fluoroquinolone that was developed exclusively for veterinary use in many animal species including, cattle, pigs, dogs, cats... etc (Altreuther 1987); and for the treatment of respiratory and enteric disease in chickens and turkeys (Anderson et al. 2003).

Due to its routine and global use in poultry industry, many generic preparations of ENRO have been developed after the original ones have been developed by Bayer ${ }^{\circledR}$ Corporation as Baytril ${ }^{\circledR}$ in different formulations.

The present study was designed to compare between two ENRO $10 \%$ oral solution preparations that are widely distributed in our local market, namely, Enrol ${ }^{\circledR}$ (Med-mac $^{\circledR}$, Amman, Jordan) as ENRO-A and Syvaquinol ${ }^{\circledR}$ (Syva ${ }^{\circledR}$, Leon, Spain) as ENRO-B.

Bioequivalence studies are generally recommended by FDA using the following endpoints: Pharmacokinetic endpoint; Pharmacodynamic endpoint; Clinical endpoint; and in vitro endpoint. The pharmacokinetic endpoint has been so often used and most reliable (Midha and McKay 2009). Products satisfying the bioequivalence requirements can reliably be assumed to produce similar clinical effects when used interchangeably in the same patient (Birkett 2003).

Pharmacokinetic parameters for the original preparations of ENRO have already been studied in poultry by many authors (Anadon et al. 1995), (Abd El-Aziz et al. 1997), (Garcia Ovando et al. 1999) and (Knoll et al. 1999). Although methodological differences in their work may limit straight forward comparisons, differences in their results are seemingly unimportant, particularly because most of these studies used the same source of ENRO that was the original preparation. However, if different sources of EN$\mathrm{RO}$ are compared, it may be reasonable to postulate that some differences may occur, particularly if different vehicles are utilized (Sumano et al. 1994) and (Sumano and Ocampo 1995).
Because changes in pharmacokinetic variables may modify therapeutics, withdrawal times and could negatively impact safety outcomes, it was regarded as important to determine whether or not commercial preparations of ENRO are bioequivalent.

In this study, pharmacokinetics and absolute bioavailabilities were compared following single i.c. administrations of two different ENRO $10 \%$ oral solution commercial brands at the recommended dose of $10 \mathrm{mg} / \mathrm{kg} \mathrm{b.w.} \mathrm{(in} \mathrm{reference} \mathrm{to} \mathrm{i.v.} \mathrm{standards)} \mathrm{to} \mathrm{healthy}$ broiler chickens.

The method used for measuring ENRO in plasma samples in this study was relatively more sensitive and more reliable than other methods such as microbiological assay. The detection limits of HPLC were reported in some studies to be about 5 folds higher than microbiology assay ( $0.02 \mathrm{vs} 0.1 \mu \mathrm{g} / \mathrm{mL}$ ) (Khan et al. 2012).

Obtained C-T data were analyzed for calculating pharmacokinetic parameters following single i.v. bolus and i.c administrations of the standard ENRO and the 2 tested oral ENRO preparations, respectively. Data of standard ENRO were just obtained as reference values to calculate absolute bioavailabilities and some other parameters of the studied ENRO oral brands. WinNonLin version 5.3 Pharmacokinetic computer program was used for analyzing C$\mathrm{T}$ data. C-T data and pharmacokinetic parameters after i.v. administration are shown in table $2 \&$ Fig. $7 \& 8$. The highest mean concentration of ENRO detected in chicken plasma was after 5 minutes being $15.25 \pm 3.89 \mu \mathrm{g} / \mathrm{mL}$, while the lowest mean concentration detected was after $24 \mathrm{~h}$ being $0.09 \pm 0.009 \mu \mathrm{g} / \mathrm{mL}$. The computer pharmacokinetic program predicted that the concentration of ENRO at zero time $\left(\mathrm{C}^{\circ}\right)$ would be $20.1 \pm 2.81 \mu \mathrm{g} / \mathrm{mL}$. This result may be comparable to that depicted by Anadon et al. (1995). The terminal half-life $\left(t_{1 / 2(\lambda)}\right)$ of ENRO in chicken plasma following single i.v. was calculated in the present study as $8.11 \pm 0.84 \mathrm{~h}$. This value may be longer than those reported by Knoll et al. (1999) (5.56 h) and Mekala et al. (2014) (6.84 h); but shorter those reported by Anadon et al. (1995) (10.29 h), Bugyei et al. (1999) $(10.96 \mathrm{~h})$ and Jakubowski et al. (2010) $(9.14 \mathrm{~h})$. These differences might be attributed to different methodology environments and/or different ages of the birds used.

AUC and AUMC were found to be $16.14 \pm 2.23 \mathrm{mg} . \mathrm{h} / \mathrm{L}$ and 99.01 $\pm 10.33 \mathrm{mg} . \mathrm{h} 2 / \mathrm{L}$, respectively. The data are inconsistent with that reported by Mekala et al. (2014) who found that AUC and AUMC were $32.72 \mu \mathrm{g} . \mathrm{h} / \mathrm{mL}$ and $282.83 \mu \mathrm{g} . \mathrm{h} 2 / \mathrm{mL}$, respectively, after single i.v. administration of $10 \mathrm{mg} / \mathrm{Kg}$ b.w. of ENRO to Cobb chickens. AUC was also inconsistent with that reported by Anadon et al. (1995) (34.51 mg.h/L) but comparable to that reported by Knoll et al. (1999) (16.17 mg.h/L) after i.v. administration of the same dose to chickens.

The $\mathrm{V}_{\mathrm{d}(\mathrm{ss})}$ of ENRO after $10 \mathrm{mg} / \mathrm{Kg}$ b.w. i.v. bolus in chickens recorded in this study was large $(3.8 \pm 0.19 \mathrm{~L} / \mathrm{Kg})$ and in accordance with value of $3.9 \mathrm{~L} / \mathrm{Kg}$ reported by Knoll et al. (1999). However, it is not in accordance with values of 2.77 and $2.92 \mathrm{~L} / \mathrm{Kg}$ reported by Anadon et al. (1995) and Bugyei et al. (1999), respectively.

The mean value of $\mathrm{Cl}_{\mathrm{B}}$ of ENRO from chicken body obtained in the present study after i.v. $10 \mathrm{mg} / \mathrm{kg}$ b.w. bolus was $0.62 \pm 0.07$ $\mathrm{L} / \mathrm{h} / \mathrm{Kg}$. This value was comparable to that reported by Knoll et al. (1999) who recorded clearance of $0.62 \mathrm{~L} / \mathrm{h} / \mathrm{Kg}$ for the same dose of ENRO. However, lower values were reported by Anadon et al. (1995) $(0.29 \mathrm{~L} / \mathrm{h} / \mathrm{Kg})$, Jakubowski et al. (2010) $(0.4 \mathrm{~L} / \mathrm{h} / \mathrm{Kg})$ and Mekala et al. (2014) $(0.31 \mathrm{~L} / \mathrm{h} / \mathrm{kg})$.

MRT can be used to estimate the average time a drug molecule spends in the body and thus helps to interpret the duration of the drug effect. It should be noted that MRT is highly influenced by the measurements in the terminal phase of $\mathrm{C}$ - $\mathrm{T}$ curve. In the present study, MRT was found to be $6.13 \mathrm{~h}$ after i.v. administration of $10 \mathrm{mg} / \mathrm{Kg} \mathrm{b}$.w. of standard ENRO. This value is inconsistent with those reported in chickens by Anadon et al. (1995) $(9.65 \mathrm{~h})$ and Mekala et al. (2014) $(8.86 \mathrm{~h})$ but is consistent with those of Knoll et al. (1999) (6.38 h) and Jakubowski et al. (2010) (6.99 h).

Following i.c. administration of a single dose of $10 \mathrm{mg} / \mathrm{Kg}$ b.w. of ENRO as $10 \%$ oral formulations to broiler chickens (table $3 \&$ 
Fig. 7, $9 \& 10$ ), therapeutic concentrations were attained $0.5 \mathrm{~h}$ post administration in all birds and was detectable up to $24 \mathrm{~h}$ in the plasma of chickens given either ENRO-A brand $\left(\right.$ Enrol $\left.^{\circledR}\right)$ or ENRO-B brand $\left(\right.$ Syvaquinol $\left.{ }^{\circledR}\right)$. Although insignificant $(p<0.05)$, the mean plasma concentrations of ENRO-A, at the different time points, were lower than those of ENRO-B, yet the concentrations in all birds included in both groups were above the reference minimum therapeutic concentration reported for ENRO in chickens $(0.008-0.06 \mu \mathrm{g} / \mathrm{mL})$. Differences in the formulations including vehicles, solvents, diluents and additives as well as pharmaceutical technology could be responsible for that difference.

The mean peak plasma concentrations $\left(\mathrm{C}_{\max }\right)$ in the present study were calculated as $1.61 \pm 0.20$ and $1.79 \pm 0.28 \mu \mathrm{g} / \mathrm{mL}$ ) in birds given ENRO-A and ENRO-B brands, respectively. Both values were lower than that reported in broilers $(2.44 \mu \mathrm{g} / \mathrm{ml})$ by Anadon et al. (1995) at the same dose level. However, the mean $C_{\max }$ values for brands recorded in the present study were comparable to 1.63 Mekala et al. (2014) and $1.88 \mu \mathrm{g} / \mathrm{ml}$ Knoll et al. (1999), respectively. On the other hand, the recorded values in the present study were higher than that recorded by Gberindyer et al. (2010) $(1 \mu \mathrm{g} / \mathrm{mL})$ following oral administration of ENRO at a higher dose level of $20 \mathrm{mg} / \mathrm{Kg}$ b.w in broiler chickens.

In the present study, $\mathrm{C}_{\max }$ values were recorded at $2 \mathrm{~h}\left(\mathrm{~T}_{\max }\right)$ in birds administered ENRO-A and ENRO-B brands. The value may be not in accordance with that of $1.68 \mathrm{~h}$ recorded by Anadon et al (1995), and of 1.5 that was recorded by Knoll et al. (1999). However, the value is consistent with that recorded $(2.0 \mathrm{~h})$ by Posyniak et al. (2001) after a single oral administration at a dose level of 10 $\mathrm{mg} / \mathrm{Kg}$ body weight. These fluctuations may be attributed to the differences in the administered ENRO sources and possible effects of the individual recipient birds.

The AUC after oral administration is a useful index for the biological availability (bioavailability) of the drug when compared to that after i.v. administration. In the present study, the mean $\mathrm{AUC}_{0} \infty$ values for the two tested ENRO-A and ENRO-B formulations were insignificantly different $(p<0.05)$ being $12.74 \pm 2.95$ and $14.35 \pm 2.85 \mathrm{mg} . \mathrm{h} / \mathrm{L}$, respectively. The present values are lower than those reported in chickens by Anadon et al. (1995) (22.26 mg.h/L), Bugyei et al. (1999) (17.4 mg.h/L) but are comparable to that recorded by Knoll et al. (1999) (14.42 mg.h/L). The differences may be attributed to different ENRO sources which may contain different excipient ingredients used in formulating the brands.

AUMC is the area under the first-order moment curve. It is the sum of products of multiplying (concentration $\mathrm{x}$ time) by (time). In non-compartmental analysis, AUMC, together with AUC, is used in calculating the total clearance $\left(\mathrm{Cl}_{\mathrm{B}}\right)$, the volume of distribution at steady-state $\left(\mathrm{V}_{\mathrm{dss}}\right)$, and the mean residence time (MRT) either manually or by computer programs. In the present study, AUMC values were recorded as $131.34 \pm 12.73$ and $149.72 \pm 5.21$ $\mathrm{mg} . \mathrm{h}^{2} / \mathrm{L}$ for ENRO-A and ENRO-B brands, respectively. The recorded values were far lower than that recorded by Mekala et al. (2014) $\left(405.06 \pm 43.29 \mu \mathrm{g} . \mathrm{h}^{2} / \mathrm{mL}\right)$ after the same dose of ENRO to chickens.

As mentioned after i.v. administration, MRT is an estimate for the average time a drug molecule spends in the body and thus determines the duration of the drug effect. It is calculated as the product of divisibility of AUMC by AUC. MRT recorded for ENRO-A and ENRO-B brands after i.c. administration of $10 \mathrm{mg} / \mathrm{kg}$ b.w. were $10.31 \pm 0.81$ and $10.43 \pm 1.94 \mathrm{~h}$, respectively. Although statistically indifferent, but they are shorter than those recorded by Anadon et al. (1995) (15.3 h), Bugyei et al. (1999) (13.7 h) and Mekala et al. (2014) (15.81 h); and longer than that reported by Knoll et al. (1999) (7.58 h).

MAT is the mean time needed by drug molecules to be absorbed i.e. to reach the blood from extravascular sites of administration (i.c. in the present study). Values of MAT recorded for ENRO-A and ENRO-B in this study were $4.17 \pm 0.22$ and $4.29 \pm 0.51 \mathrm{~h}$, respectively. Although indifferent, they are longer than that recorded by Knoll et al. (1999) (1.2 h) and shorter than that recorded by Mekala et al. (2014) $(6.95 \mathrm{~h})$.
Volume of drug distribution in non-compartmental analysis after oral administration, is calculated as $\mathrm{V}_{\mathrm{z}}$ which is the overall volume of distribution at the terminal phase in terms of AUC and bioavailability. In the present study, $\mathrm{V}_{\mathrm{z}}$ for ENRO-A and ENRO-B were computed as $7.5 \pm 0.78$ and $7.56 \pm 0.99 \mathrm{~L} / \mathrm{Kg}$, respectively. These values are larger than those recorded by Anadon et al. (1995) $(5.94 \mathrm{~L} / \mathrm{Kg})$ and by Mekala et al. (2014) $(4.69 \mathrm{~L} / \mathrm{Kg})$. Drugs with apparent volume of distribution larger than $1 \mathrm{~L} / \mathrm{Kg}$ are considered to be widely distributed in the body fluids (Baggot 1977); accordingly, both ENRO brands evaluated in the present study were thus judged to be widely distributed into chicken body fluids as reflected by their large $\mathrm{V}_{\mathrm{z}}$.

Clearance $\left(\mathrm{Cl}_{\mathrm{B}}\right)$ is determined as the volume of blood cleared from the drug per time. The values recorded for ENRO-A and ENRO-B in the present study were almost similar, being $0.6195 \pm 0.164$ and $0.6196 \pm 0.177 \mathrm{~L} / \mathrm{h} / \mathrm{Kg}$. The value is larger than that recorded by Anadon et al. (1995) $(0.288 \mathrm{~L} / \mathrm{h} / \mathrm{Kg})$ and Mekala et al. (2014) $(0.318 \mathrm{~L} / \mathrm{h} / \mathrm{Kg})$.

The absolute bioavailabilities computed for brands A and B of ENRO were statistically $(p<0.05)$ indifferent and were $78.96 \pm$ 6.73 and $88.94 \pm 10.89 \%$, respectively, from the administered 10 $\mathrm{mg} / \mathrm{Kg}$ b.w. oral dose. The values were different from those recorded in previous studies in chickens as $64 \%$ (Anadon et al. 1995), 59.6 \% (Abd El-Aziz et al. 1997), $80.1 \%$ (Bugyei et al. 1999), $89.2 \%$ (Knoll et al. 1999) and $77.47 \%$ (Mekala et al. 2014). The present results confirmed that ENRO is well absorbed after oral administration in chicken. However, the bioavailability was better from ENRO-B than that from ENRO-A.

According to the FDA and EMA regulations, which state that intervals for the ratios of AUC, $\mathrm{C}_{\max }$ and bioavailability must fall between $80 \%$ and $125 \%$, it could be concluded that both brands ENRO-A and ENRO-B are bioequivalent to each other hence the targeted ratios were calculated as $88.78 \%$ (AUC), $89.94 \%\left(\mathrm{C}_{\max }\right)$ and $88.78 \%$ (bioavailability) and the $\mathrm{T}_{\max }$ values were almost similar. Nevertheless, the parameters of ENRO-B were superior to those of ENRO-A.

\section{Conclusion}

It could be concluded that despite the superior pharmacokinetic profile of ENRO-B (Syvaquinol ${ }^{\circledR}$, Syva $^{\circledR}$, Leon, Spain) over ENRO-A (Enrol ${ }^{\circledR}$, Medmac $^{\circledR}$, Amman, Jordan), both generic preparations, however, are within the FDA and EMA bioequivalence acceptance range of $80 \%-125 \%$ and thus can be used as interchangeable therapeutic agents in chickens.

\section{Acknowledgements}

The authors would like to thank their colleague Hanady Awadallah for kind help in blood sampling; and thank Mr. Ali Ammar at Biotechnology Research Center, At-Twaishah, Libya for giving a hand in HPLC.

\section{References}

[1] Abd El-Aziz M, Aziz M, Soliman F \& Afify N 1997, Pharmacokinetic evaluation of enrofloxacin in chickens. British poultry science 38, 164-168. http://dx.doi.org/10.1080/00071669708417963.

[2] Altreuther P 1987, [Data on chemistry and toxicology of Baytril]. Veterinaer-Medizinische Nachrichten (Germany, FR).

[3] Anadon A, Martinez Larranaga MR, Diaz MJ, Fernandez- cruze ML, Martinez MA, Bringas P, Fernandez MC \& Fernandez R 1995 Pharmacokinetics and residues of enrofloxacin in chickens. American journal of Veterinary Research 56, 501-506.

[4] Anderson AD, Nelson JM, Rossiter S \& Angulo FJ 2003, Public health consequences of use of antimicrobial agents in food animals in the United States. Microbial Drug Resistance 9, 373-379. http://dx.doi.org/10.1089/107662903322762815.

[5] Baggot JD 1977, Principles of drug disposition in domestic animals the basis of veterinary clinical pharmacology: WB Saunders. 
[6] Ball P 2000, Quinolone generations: natural history or natural selection? Journal of Antimicrobial Chemotherapy 46, 17-24. http://dx.doi.org/10.1093/oxfordjournals.jac.a020889.

[7] Birkett DJ 2003, Generics-equal or not? Australian Prescriber 26, 85-86. http://dx.doi.org/10.18773/austprescr.2003.063.

[8] Bugyei K, Black WD \& McEwen S 1999, Pharmacokinetics of enrofloxacin given by the oral, intravenous and intramuscular routes in broiler chickens. Canadian Journal of Veterinary Research 63, 193-200.

[9] EMA CfMPfHU 2010, Guideline on the investigation of bioequivalence. European Medicines Agency (EMA), London.

[10] FDA 2005, Food and Drug Administration final decision of the Commissioner. Docket no. 2000n-1571. Withdrawal of approval of the new animal drug application for enrofloxacin in poultry.

[11] FDA 2015, Bioavailability and bioequivalence requirements, Subpart B-Procedures for Determining the Bioavailability or Bioequivalence of Drug Products. In: CFR - Code of Federal Regulations Title 21. USA.

[12] Garcia Ovando H, Gorla N, Luders C, Poloni G, Errecalde C, Prieto G \& Puelles I 1999, Comparative pharmacokinetics of enrofloxacin and ciprofloxacin in chickens. Journal of Veterinary Pharmacology and Therapeutics 22, 209-212. http://dx.doi.org/10.1046/j.13652885.1999.00211.x.

[13] Gberindyer FA, Noel Wannang N \& Akwuobu CA 2010, Comparative pharmacokinetics/pharmacodynamic modeling on three brands of $10 \%$ enrofloxacin oral formulations in broiler chickens. International Journal of Poultry Science 9, 273-277. http://dx.doi.org/10.3923/ijps.2010.273.277.

[14] Gellert M, Mizuuchi K, O'Dea MH, Itoh T \& Tomizawa J-I 1977, Nalidixic acid resistance: a second genetic character involved in DNA gyrase activity. Proceedings of the National Academy of Sciences 74, 4772-4776. http://dx.doi.org/10.1073/pnas.74.11.4772.

[15] Gibaldi M \& Perriere D 2007, Pharmacokinetics In: Noncompartmental Analysis Based on Statistical Moment Theory, 2nd ed. New York, USA: Informa Healthcare. p 409-417.

[16] Heitzman RJ 1997, Enrofloxacin In: Identity. Berkshire, United Kingdom. p 31-44.

[17] Jakubowski P, Jaroszewski J, Grabowski T, Markiewicz W \& Maslanka T 2010, Determination of enrofloxacin in chicken plasma by high performance liquid chromatography for pharmacokinetic studies. Acta veterinaria 60, 563-572. http://dx.doi.org/10.2298/AVB1006563J.

[18] Khan MK, Khan MF, Mustafa G \& Sualah M 2012, Comparison of High-Pressure Liquid Chromatography and microbiological assay for determination of ciprofloxacin tablets in human plasma employed in bioequivalence and pharmacokinetics study. Pak J Pharm Sci 25, 81-88.

[19] Knoll U, Glünder G \& Kietzmann M 1999, Comparative study of the plasma pharmacokinetics and tissue concentrations of danofloxacin and enrofloxacin in broiler chikens. Journal of Veterinary Pharmacology and Therapeutics 22, 239-246. http://dx.doi.org/10.1046/j.1365-2885.1999.00217.x.

[20] Küng K, RIOND JL \& Wanner M 1993, Pharmacokinetics of enrofloxacin and its metabolite ciprofloxacin after intravenous and oral administration of enrofloxacin in dogs. Journal of Veterinary Pharmacology and Therapeutics 16, 462-468.

[21] Lesher GY, Froelich EJ, Gruett MD, Bailey JH \& Brundage RP 1962, 1, 8-Naphthyridine derivatives. A new class of chemotherapeutic agents. Journal of Medicinal Chemistry 5, 1063-1065. http://dx.doi.org/10.1021/jm01240a021.

[22] Mekala P, Jagadeeswaran A, Arivuchelvan A, Senthilkumar P, Nanjappan K \& Krishnamurthy TG 2014, Pharmacokinetics of Enrofloxacin after Single Intravenous and Oral Bolus Administration in Broiler Chicken. International Journal of Advanced Veterinary Science and Technology 3, pp. 99-105.

[23] Midha KK \& McKay G 2009, Bioequivalence; its history, practice, and future. The AAPS journal 11, 664-670. http://dx.doi.org/10.1208/s12248-009-9142-z.

[24] Nielsen P \& Gyrd-Hansen N 1997, Bioavailability of enrofloxacin after oral administration to fed and fasted pigs. Pharmacology \& toxicology $\quad 80, \quad 246-250 . \quad$ http://dx.doi.org/10.1111/j.16000773.1997.tb01967.x.

[25] Posyniak A, Zmudzki J, Niedzielska J \& Biernacki B 2001, Bioequivalence study of two formulations of enrofloxacin following oral administration in chickens. Bulletin of the Veterinary Research Institute in Pulawy 45, 353-358.

[26] Rao G, Ramesh S, Ahmad A, Tripathi H, Sharma L \& Malik J 2002, Disposition kinetics of enrofloxacin and ciprofloxacin following intravenous administration of enrofloxacin in goats. Small Ruminant
Research $\quad 44, \quad 9-15 . \quad$ http://dx.doi.org/10.1016/S0921 4488(02)00003-2.

[27] Sumano H \& Ocampo L 1995, Compositional Analysis Surveillance of Eleven Brands of Enrofloxacin Including Baytril® for Veterinary Use. Journal of Veterinary Medicine Series A 42, 669-673. http://dx.doi.org/10.1111/j.1439-0442.1995.tb00421.x.

[28] Sumano L, Gomez R, Gracia M \& Ruiz-Ramirez L 1994, The use of ciprofloxacin in veterinary proprietary products of enrofloxacin. Veterinary and human toxicology 36, 476-477.

[29] Van Bambeke F, Michot JM, Van Eldere J \& Tulkens PM 2005, Quinolones in 2005: an update. Clinical Microbiology and infection 11, 256-280. http://dx.doi.org/10.1111/j.1469-0691.2005.01131.x. 